\title{
Weissella beninensis sp. nov., a motile lactic acid bacterium from submerged cassava fermentations, and emended description of the genus Weissella
}

Correspondence

Dennis S. Nielsen dn@life.ku.dk
Sègla Wilfrid Padonou, ${ }^{1,2}$ Ulrich Schillinger, ${ }^{3}$ Dennis S. Nielsen, ${ }^{4}$ Charles M. A. P. Franz, ${ }^{5}$ Michael Hansen, ${ }^{6}$ Joseph D. Hounhouigan, ${ }^{1}$ Mathurin C. Nago ${ }^{1}$ and Mogens Jakobsen ${ }^{4}$

\author{
${ }^{1}$ Departement de Nutrition et Sciences Alimentaires, Faculté des Sciences Agronomiques, \\ Université d'Abomey-Calavi, Cotonou, Bénin \\ ${ }^{2}$ Programme Technologie Agricole et Alimentaire, Institut National des Recherches Agricoles du \\ Bénin, 01 BP 128 Porto-Novo, Bénin \\ ${ }^{3}$ Department of Microbiology and Biotechnology, Max Rubner-Institut, Federal Research Institute of \\ Nutrition and Food, Karlsruhe, Germany \\ ${ }^{4}$ Department of Food Science, Food Microbiology, Center for Advanced Food Studies (LMC), \\ Faculty of Life Sciences, University of Copenhagen, Denmark \\ ${ }^{5}$ Department of Safety and Quality of Fruit and Vegetables, Max Rubner-Institut, Federal Research \\ Institute of Nutrition and Food, Karlsruhe, Germany \\ ${ }^{6}$ Department of Plant Biology and Biotechnology, Faculty of Life Sciences, \\ University of Copenhagen, Denmark
}

Four Gram-positive, catalase-negative, short rod-shaped or coccoid, heterofermentative lactic acid bacterial strains (2L24P13 ${ }^{\top}, 1 \mathrm{~L} 48 \mathrm{P} 15,1 \mathrm{~L} 24 \mathrm{P} 31$ and 1L24P34) with unusual phenotypic and genotypic properties were isolated from submerged fermenting cassava on MRS agar. All strains were motile, grew at $15{ }^{\circ} \mathrm{C}$, produced DL-lactic acid from glucose with gas formation and produced ammonia from arginine. Acid was produced from D-fructose, D-galactose, D-glucose, lactose, maltose, D-mannose, melibiose, D-raffinose, sucrose, $\mathrm{N}$-acetylglucosamine and D-mannitol, but not from D-arabinose or xylose. 16S rRNA gene sequence analysis revealed that the strains belonged to the genus Weissella and were most closely related to Weissella ghanensis LMG $24286^{\top}$. Low DNA-DNA reassociation values were obtained between the isolates and $W$. ghanensis DSM $19935^{\top}$. Based on the genetic and phenotypic results, the strains are considered to represent a novel species, for which the name Weissella beninensis sp. nov. is proposed. The type strain is $2 \mathrm{~L}_{24 \mathrm{P} 13^{\top}}\left(=\mathrm{DSM} 22752^{\top}=\mathrm{LMG} 25373^{\top}\right)$.
Cassava, the most widespread root crop in developing countries, is processed in several ways before consumption. A well-known method that is widely practiced in Africa is lactic acid fermentation (Cooke et al., 1987; Nout \& Motarjemi, 1997). Cassava fermentation is a complex process that involves the activities of various microorganisms and leads to the production of various food products such as gari, agbelima, attiéké, fufu and lafun. Several types of micro-organisms have been reported to be associated with such fermentations but lactic acid bacteria (LAB) predominate (Amoa-Awua et al., 1996; Caplice \&

Abbreviations: LAB, lactic acid bacteria; SEM, scanning electron microscopy.

The GenBank/EMBL/DDBJ accession number for the $16 \mathrm{~S}$ rRNA gene sequence of strain $2 \mathrm{~L}^{24 \mathrm{P} 13^{\top}}$ is EU439435.
Fitzgerald, 1999; Nout \& Sarkar, 1999; Kostinek et al., 2005; Coulin et al., 2006). In a previous study, we identified the micro-organisms associated with submerged cassava root fermentation for lafun production to species level, among which four LAB strains, isolated from MRS agar (Merck), had unusual phenotypic and genotypic properties and were tentatively identified as species of the genus Weissella (Padonou et al. 2009). This study reports the morphological, biochemical and molecular characterization of these strains, designated 2L24P13 ${ }^{\mathrm{T}}, 1 \mathrm{~L} 48 \mathrm{P} 15,1 \mathrm{~L} 24 \mathrm{P} 31$ and 1L24P34.

The four isolates and the reference strains Weissella koreensis DSM $15830^{\mathrm{T}}$, W. kandleri DSM 20593 ${ }^{\mathrm{T}}$, W. soli DSM $14420^{\mathrm{T}}$ and $W$. ghanensis DSM $19935^{\mathrm{T}}$ were maintained in MRS broth at $30{ }^{\circ} \mathrm{C}$ for $2-3$ days and stored in MRS medium with $20 \%(\mathrm{v} / \mathrm{v})$ glycerol at $-80{ }^{\circ} \mathrm{C}$. 
After growth for 4 days at $30{ }^{\circ} \mathrm{C}$ on MRS agar under anaerobic conditions, all four isolates exhibited colonies that were 1-2 $\mathrm{mm}$ in diameter, white to creamish white, smooth, circular and convex. Cell morphology was determined after overnight growth in MRS broth at $30{ }^{\circ} \mathrm{C}$ using phase-contrast microscopy and scanning electron microscopy (SEM). A $30 \mu \mathrm{l}$ sample of the culture was diluted 10-fold with sterile MilliQ-water and filtered through a polycarbonate filter (pore size $0.2 \mu \mathrm{m}$ ). While still attached to the filter, the bacteria were dehydrated with a graded ethanol series, dried with hexamethyldisilazane, fixed with glutaraldehyde and osmium tetroxide, coated with gold/palladium and observed using a FEI Quanta 200 microscope at an acceleration voltage of $30 \mathrm{kV}$. Cells were short rod-shaped or coccoid, $0.7-0.9 \mu \mathrm{m}$ wide and 0.9$1.5 \mu \mathrm{m}$ long, occurring singly, in pairs or in short chains (Fig. 1a, b). Motility was observed for all four isolates under the phase-contrast microscope, although the motility was variable and sometimes only a small fraction of a population was actively moving. Peritrichous flagella were observed using SEM (Fig. 1b, c).

The Gram reaction was determined using the $\mathrm{KOH}$ method (Gregersen, 1978). Catalase activity was tested by the standard method using $3 \% \mathrm{H}_{2} \mathrm{O}_{2}$. Growth was determined at 15 and $45{ }^{\circ} \mathrm{C}$, with $4,6.5$ and $10 \%(\mathrm{w} / \mathrm{v}) \mathrm{NaCl}$ and at pH 3.9 and 8.0 in MRS broth. Gas production from glucose was examined in MRS broth with citrate omitted at $30{ }^{\circ} \mathrm{C}$, using inverted Durham tubes to collect the gas. Production of ammonia from arginine and formation of dextran from sucrose were tested following the protocol of Schillinger \& Lücke (1987). The configuration of the lactic acid enantiomer was determined enzymically (Roche Diagnostic) (Schillinger \& Lücke, 1987). Carbohydrate fermentation patterns were determined in microtitre plates following the protocol of Jayne-Williams (1976) and using the API $50 \mathrm{CH}$ system (bioMérieux). The results of these phenotypic tests are given in Table 1 and the species description.

For all four isolates, the nearly complete $16 \mathrm{~S}$ rRNA gene sequence was determined as described below. DNA was extracted according to the method of Pitcher et al. (1989), as modified for Gram-positive bacteria (Björkroth \& Korkeala, 1996). The $16 \mathrm{~S}$ rRNA gene was amplified by PCR and amplification products were purified and commercially sequenced at GATC Biotech as described previously (Kostinek et al., 2005). Sequences were manually corrected and aligned using Vector NTI Suite 10. The closest phylogenetic relatives were determined by aligning the corrected sequences with 16S rRNA gene sequences in the GenBank database by using the BLAST algorithm (Altschul et al., 1997). Strains 2L24P13 ${ }^{\mathrm{T}}$, 1L48P15, 1L24P31 and 1L24P34 had identical 16S rRNA gene sequences. The $16 \mathrm{~S}$ rRNA gene sequences of the four isolates and their closest phylogenetic relatives were aligned and phylogenetic trees were constructed with the neighbour-joining, maximum-likelihood and maximumparsimony methods using Bionumerics version 4.5 (Applied Maths). Unknown bases were discarded from the analysis and 1450 nucleotides were included. The statistical reliability of the topology of the phylogenetic trees was evaluated using bootstrap calculations with 1000 resamplings. As seen from the maximum-parsimony tree (Fig. 2), the four strains, represented here by strain $2 \mathrm{~L} 24 \mathrm{P} 13^{\mathrm{T}}$, and $W$. ghanensis $\mathrm{LMG} 24286^{\mathrm{T}}$ formed a distinct subgroup within the genus Weissella. Similar results were obtained with the neighbour-joining and maximum-likelihood methods (results not shown). Comparison of the $16 \mathrm{~S}$ rRNA gene sequence of strain $2 \mathrm{~L} 24 \mathrm{P} 13^{\mathrm{T}}$ revealed the highest 16S rRNA gene sequence similarity with W. ghanensis LMG $24286^{\mathrm{T}}(97.3 \%)$ and lower similarities with W. confusa JCM 1093 ${ }^{\mathrm{T}}$,W. cibaria NRIC 0136 and $W$. koreensis S-5623 ${ }^{\mathrm{T}}$ (92-94\%).

PCR with genus-specific primers demonstrated that the four isolates belonged to the genus Weissella: all of them produced a $1.2 \mathrm{~kb}$ fragment with the Weissella-specific primer Weissgrp (5'-GATGGTTCTGCTACCACTAAG-3'), using the procedure described by Schillinger et al. (2008). The four isolates were further investigated by two genotyping methods: repetitive element palindromic (rep)-PCR, using the primer GTG $_{5}$ (5'-GTGGTGGTGGTGGTG-3') and following the method of Gevers et al. (2001) for LAB as described by Franz et al. (2006), and randomly amplified
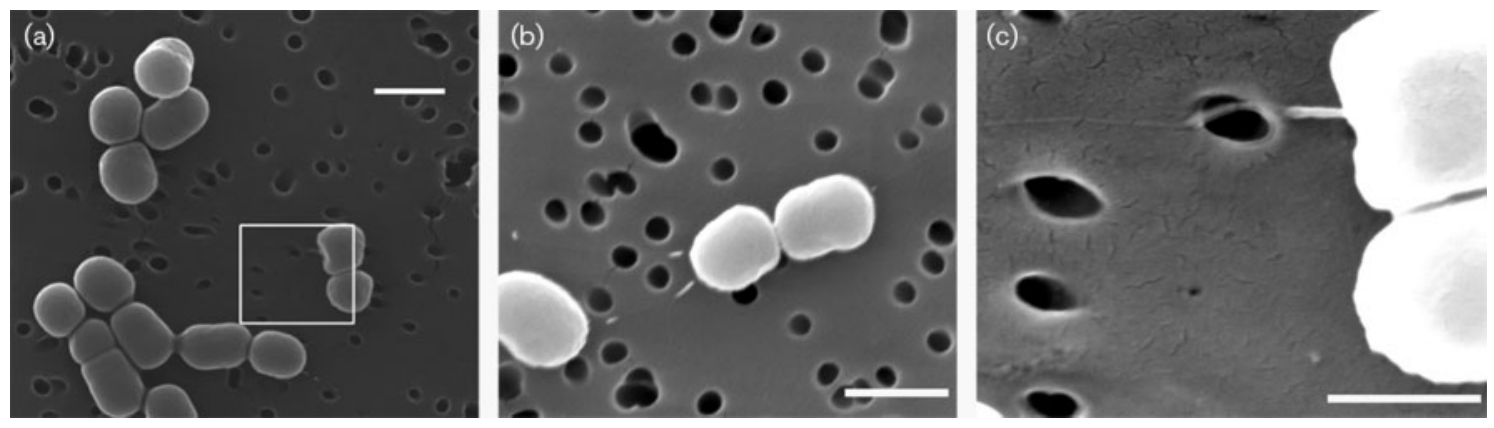

Fig. 1. Scanning electron micrographs of cells $(a, b$ and $c)$ and flagella $(b$ and $c)$ of strain $2 L 24 P 13^{\top}$ grown overnight in MRS broth at $30{ }^{\circ} \mathrm{C}$. Bars, $1 \mu \mathrm{m}(\mathrm{a}, \mathrm{b}), 0.5 \mu \mathrm{m}$ (c). 
Table 1. Differential characteristics of Weissella beninensis sp. nov. strains and other Weissella species

Taxa: 1, Weissella beninensis sp. nov. ( $n=4) ; 2$, W. cibaria LMG $17699^{\mathrm{T}} ; 3$, W. confusa JCM $1093^{\mathrm{T}} ; 4$, W. ghanensis $\mathrm{LMG}^{24286^{\mathrm{T}}} ; 5$, W. halotolerans LMG $9469^{\mathrm{T}} ; 6$, W. hellenica LMG $15125^{\mathrm{T}} ; 7$, W. kandleri DSM $20593^{\mathrm{T}} ; 8$, W. koreensis JCM $11263^{\mathrm{T}} ; 9$, W. minor LMG 9847 ${ }^{\mathrm{T}}$; 10 , W. paramesenteroides LMG 9852 ; 11, W. soli LMG 20113 $; 12$, W. thailandensis JCM 10695 ${ }^{\mathrm{T}} ; 13$, W. viridescens LMG $3507^{\mathrm{T}}$. Data were taken from this study and Collins et al. (1993), Tanasupawat et al. (2000), Björkroth et al. (2002), Magnusson et al. (2002), Lee et al. (2002), Choi et al. (2002), Ennahar \& Cai (2004) and De Bruyne et al. (2008). +, $90 \%$ or more of strains positive; v, 11-89\% of strains positive;,$- 10 \%$ or less of strains positive; ND, no data available.

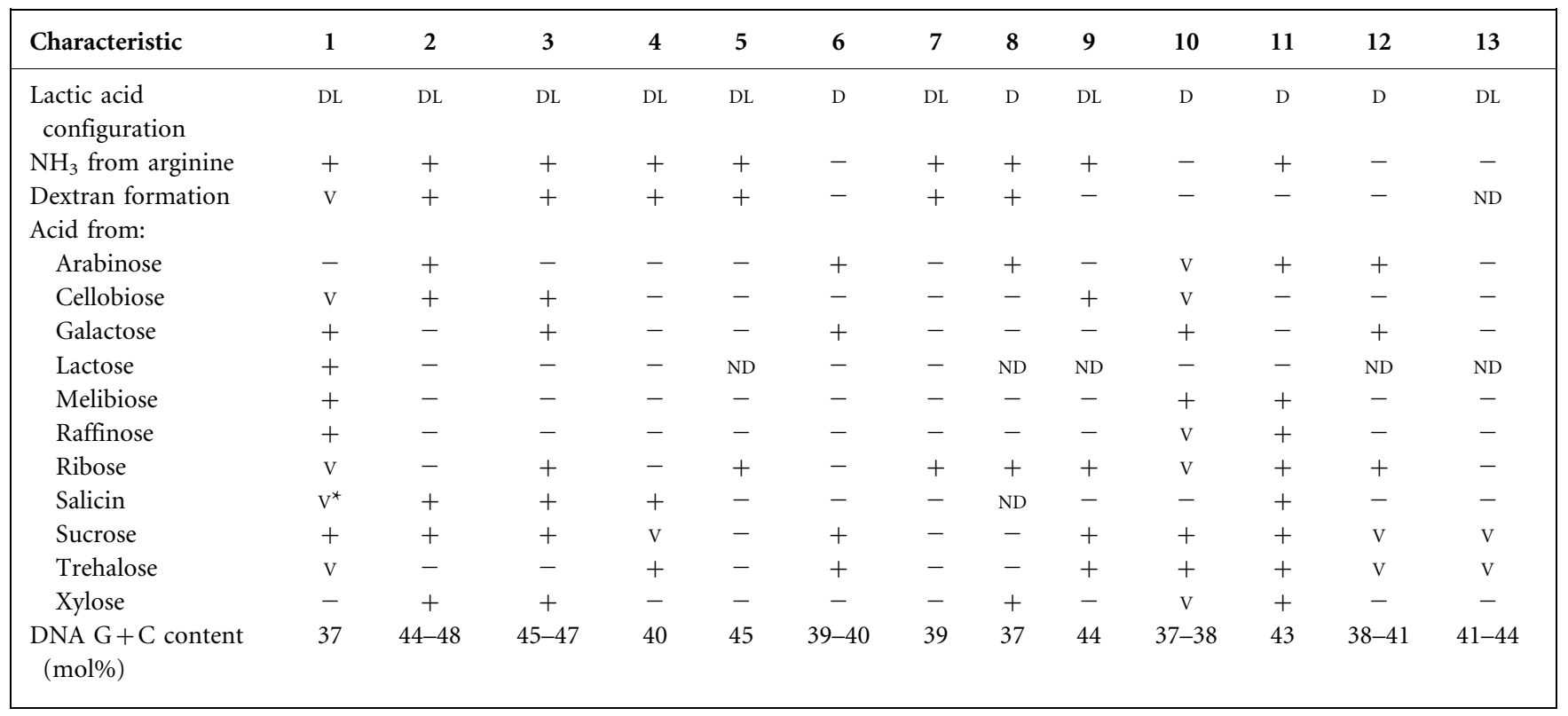

${ }^{\star}$ Delayed reaction.

polymorphic DNA (RAPD)-PCR, using primer M13 (5'GAGGGTGGCGGTTCT-3') or primer AP4 (5'-TCACGCTGCA-3'; Andrighetto et al., 2001). A dendrogram was derived using the unweighted pair group method with arithmetic averages linkage of correlation coefficients (Fig. 3). Strains $2 \mathrm{~L} 24 \mathrm{P} 13^{\mathrm{T}}, 1 \mathrm{~L} 48 \mathrm{P} 15,1 \mathrm{~L} 24 \mathrm{P} 31$ and $1 \mathrm{~L} 24 \mathrm{P} 34$ clustered closely together $(r=90-95 \%)$ and clustered with strains of W. koreensis, W. kandleri, W. soli and W. ghanensis with a low correlation $(r=12-20 \%)$.

For determination of $\mathrm{G}+\mathrm{C}$ content and DNA-DNA relatedness, DNA was extracted from the four isolates and W. ghanensis DSM $19935^{\mathrm{T}}$ and purified following the protocol of Marmur (1961) as modified by Stackebrandt \&

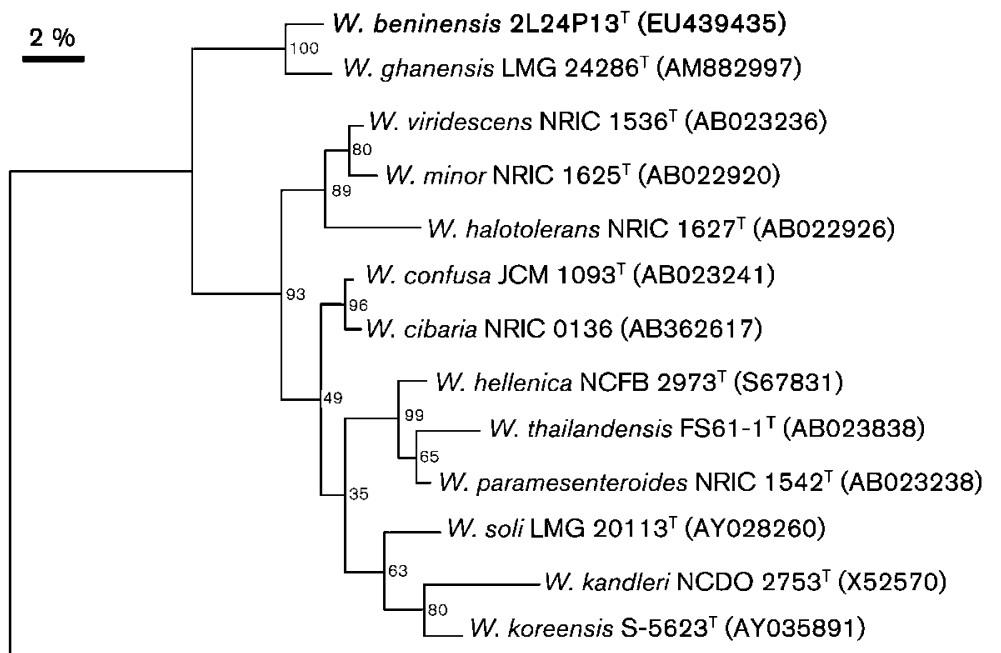

Bifidobacterium bifidum ATCC $29521^{\top}$ (M38018)
Fig. 2. Maximum-parsimony phylogenetic tree based on almost-complete 16S rRNA gene sequences showing the phylogenetic positions of strain $2 \mathrm{~L} 24 \mathrm{P} 13^{\top}$ and strains of the species of the genus Weissella. Percentages at nodes are bootstrap values based on 1000 resamplings. Bar, $2 \%$ sequence divergence. 


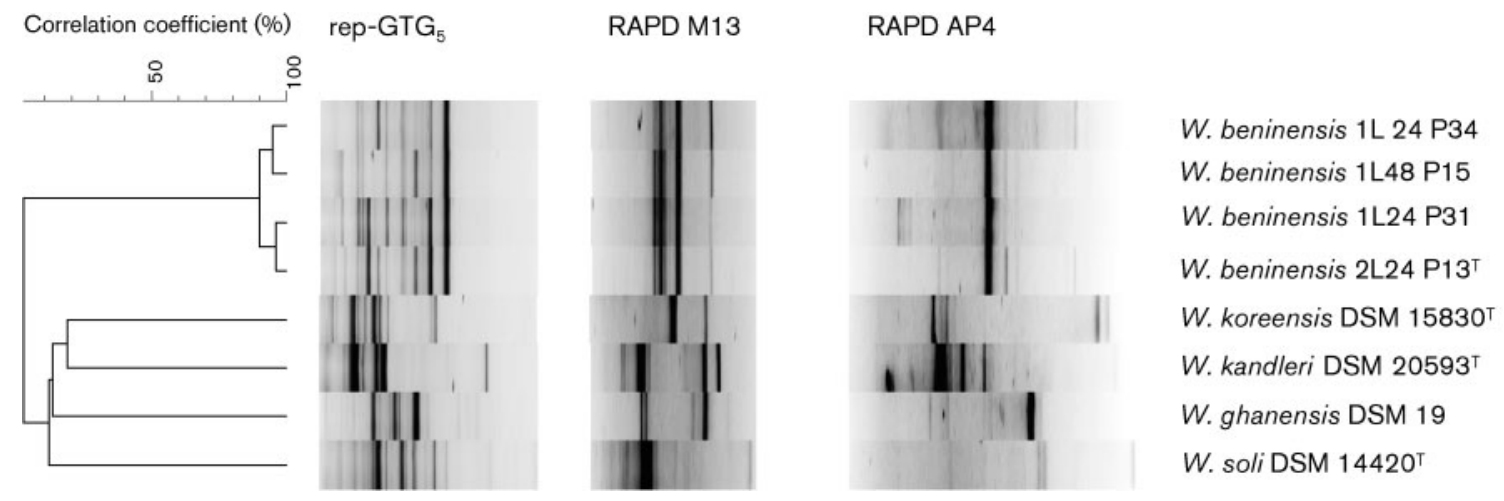

Fig. 3. rep-GTG $\mathrm{G}_{5}$ and RAPD PCR fingerprints and a corresponding dendrogram for Weissella beninensis sp. nov. and closely related strains of species of the genus Weissella.

Kandler (1979). The G + C content of DNA was determined by a modification of the fluorometric method described by Gonzalez \& Saiz-Jimenez (2002) using a iQ5 real-time thermocycler (Bio-Rad). Thermal denaturation was performed in $1 \times$ standard saline citrate with $25 \mu \mathrm{g}$ genomic DNA and $20 \times$ EvaGreen (Biotrend Chemicals) as the fluorescent dye. DNA of six LAB strains with completely sequenced genomes was used to create a calibration curve of $\mathrm{G}+\mathrm{C}$ values versus the melting temperatures ( $T_{\mathrm{m}}$ values) measured with the thermocycler. Regression analysis was performed to derive a formula for the calculation of the $\mathrm{G}+\mathrm{C}$ content in mol\%. DNA-DNA relatedness was determined using the fluorometric method of Jakava-Viljanen et al. (2008) with EvaGreen and a real-time thermocycler. Genomic DNA from strains 2L24P13 ${ }^{\mathrm{T}}$, 1L48P15, 1L24P31 and 1L24P34 were hybridized to each other and to $W$. ghanensis DSM $19935^{\mathrm{T}}$. The $\mathrm{G}+\mathrm{C}$ contents of strains $2 \mathrm{~L} 24 \mathrm{P} 13^{\mathrm{T}}, 1 \mathrm{~L} 48 \mathrm{P} 15$, 1L24P31 and 1L24P34 were 37.0-37.2 mol\%, which can be compared with the $\mathrm{G}+\mathrm{C}$ content of $40 \mathrm{~mol} \%$ for $W$. ghanensis LMG $24286^{\mathrm{T}}$ (De Bruyne et al., 2008; Table 1). The DNA-DNA relatedness values between strains $2 \mathrm{~L} 24 \mathrm{P} 13^{\mathrm{T}}$, 1L48P15, 1L24P31 and 1L24P34 were 84-122\%, which indicated that the strains are con-specific, and between the four isolates and W. ghanensis DSM $19935^{\mathrm{T}}$ they were 19$42 \%$. Thus, DNA-DNA relatedness values between each isolate and its closest relative were well below the $70 \%$ cut-off value recommended to indicate separate species (Wayne et al., 1987).

Based on the morphological, physiological and genetic characteristics described above, strains $2 \mathrm{~L} 24 \mathrm{P} 13^{\mathrm{T}}, 1 \mathrm{~L} 48 \mathrm{P} 15$, 1L24P31 and 1L24P34 clearly formed a homogeneous genetically distinct group that was most closely related to $W$. ghanensis. In addition to their genotypic characteristics, the four isolates could be clearly differentiated from their phenotypic and genotypic closest relatives by their motility and ability to produce acid from raffinose, melibiose and lactose. In conclusion, the isolates represent a novel species in the genus Weissella, for which the name Weissella beninensis sp. nov. is proposed, with strain $2 \mathrm{~L} 24 \mathrm{P} 13^{\mathrm{T}}$ as the type strain. Weissella beninensis sp. nov. represents the first description of a motile species within the genus Weissella. Therefore, the genus Weissella described by Collins et al. (1993) should be emended.

\section{Emended description of the genus Weissella Collins et al. 1993}

This description is based on that given by Collins et al. (1993). Cells are generally short rods with rounded to tapered ends or coccoid in shape occurring singly, in pairs or in short chains. Cells are Gram-positive and non-motile, with the exception of $W$. beninensis where all known strains are motile. Endospores are not formed. Catalase and cytochromes are not produced. Chemo-organotrophs with complex nutritional requirements. Heterofermentative. The configuration of lactic acid produced from glucose is either DL- or (-)-D, depending on the species. Acidoduric. Growth occurs at $15{ }^{\circ} \mathrm{C}$, but not at $45{ }^{\circ} \mathrm{C}$ (with the exception of some strains of $W$. confusa). Strains of some species hydrolyse arginine. The cell-wall peptidoglycan is based upon lysine; the interpeptide bridge contains alanine or serine and alanine as typical constituents. The $\mathrm{G}+\mathrm{C}$ content of DNA is $37-47 \mathrm{~mol} \%$. The type species is Weissella viridescens.

\section{Description of Weissella beninensis sp. nov.}

Weissella beninensis (ben.in.en'sis. N.L. fem. adj. beninensis pertaining to Benin, where the type strain was isolated).

Cells are Gram-positive, catalase-negative and short rodshaped or coccoid $(0.7-0.9 \times 0.9-1.5 \mu \mathrm{m})$. Motile with peritrichous flagella. Non-spore-forming. Occur singly, in pairs or in short chains. Colonies are $1-2 \mathrm{~mm}$ in diameter, white to creamish white, smooth, circular and convex after 3-4 days of anaerobic growth. Grows at $15{ }^{\circ} \mathrm{C}$, at $\mathrm{pH} 3.9-8.0$ and with $4 \% \mathrm{NaCl}$. No growth at $45^{\circ} \mathrm{C}$. Ammonia is produced from arginine and gas is produced from glucose. (-)-D- and (+)-L-lactic acid are produced as end products of glucose metabolism. Dextran is formed 
from sucrose by most strains. Acid is produced from Larabinose, D-fructose, D-glucose, D-galactose, $\beta$-gentiobiose, lactose, maltose, D-mannose, melibiose, D-raffinose, sucrose, D-mannitol, sorbitol, $\mathrm{N}$-acetylglucosamine, amygdalin, arbutin, aesculin. Acid production from ribose, salicin (delayed reaction), cellobiose and trehalose is straindependent. Does not ferment D-arabinose, D- or L-fucose, D-lyxose, rhamnose, L-sorbose, D-tagatose, trehalose, Dturanose, D- or L-xylose, adonitol, D- or L-arabitol, dulcitol, erythritol, glycerol, inositol, xylitol, methyl $\alpha$-D-glucoside, methyl $\alpha$-D-mannoside, methyl $\beta$-xyloside, inulin, starch, gluconate, glycogen or 2- or 5-ketogluconate. The $\mathrm{G}+\mathrm{C}$ content is $37.0-37.2 \mathrm{~mol} \%$.

The type strain is $2 \mathrm{~L} 24 \mathrm{P} 13^{\mathrm{T}}\left(=\mathrm{DSM} \quad 22752^{\mathrm{T}}=\mathrm{LMG}\right.$ $\left.25373^{\mathrm{T}}\right)$, isolated from cassava fermentations in Ketou, Benin.

\section{Acknowledgements}

The work was financed through the ENRECA/DANIDA project, 'Capability Building for Research and Quality Assurance in Traditional Food Processing in West Africa'.

\section{References}

Altschul, S. F., Madden, T. L., Schäffer, A. A., Zhang, J., Zhang, Z., Miller, W. \& Lipman, D. J. (1997). Gapped BLAST and PSI-BLAST: A new generation of protein database search programs. Nucleic Acids Res 25, 3389-3402.

Amoa-Awua, W. K. A., Appoh, F. E. \& Jakobsen, M. (1996). Lactic acid fermentation of cassava dough into agbelima. Int J Food Microbiol 31, 87-98.

Andrighetto, C., Knijff, E., Lombardi, A., Torraini, S., Vancanneyt, M., Kersters, K., Swings, J. \& Dellaglio, F. (2001). Phenotypic and genetic diversity of enterococci isolated from Italian cheeses. J Dairy Res $\mathbf{6 8}$, 303-316.

Björkroth, J. \& Korkeala, H. J. (1996). Evaluation of Lactobacillus sake contamination in vacuum-packaged sliced cooked meat products by ribotyping. J Food Prot 59, 398-401.

Björkroth, K. J., Schillinger, U., Geisen, R., Weiss, N., Hoste, B., Holzapfel, W. H., Korkeala, H. J. \& Vandamme, P. (2002). Taxonomic study of Weissella confusa and description of Weissella cibaria sp. nov., detected in food and clinical samples. Int J Syst Evol Microbiol 52, 141-148.

Caplice, E. \& Fitzgerald, G. F. (1999). Food fermentations: role of microorganisms in food production and preservation. Int $J$ Food Microbiol 50, 131-149.

Choi, H.-J., Cheigh, C.-I., Kim, S.-B., Lee, J.-C., Lee, D.-W., Choi, S.-W., Park, J.-M. \& Pyun, Y.-R. (2002). Weissella kimchii sp. nov., a novel lactic acid bacterium from kimchi. Int J Syst Evol Microbiol 52, 507511.

Collins, M. D., Samelis, J., Metaxopoulos, J. \& Wallbanks, S. (1993). Taxonomic studies on some leuconostoc-like organisms from fermented sausages: description of a new genus Weissella for the Leuconostoc paramesenteroides group of species. J Appl Bacteriol 75, 595-603.

Cooke, R. D., Twiddy, D. R. \& Reilly, P. J. A. (1987). Lactic-acid fermentation as a low-cost means of food preservation in tropical countries. FEMS Microbiol Rev 46, 369-379.
Coulin, P., Farah, Z., Assanvo, J., Spillmann, H. \& Puhan, Z. (2006). Characterisation of the microflora of attiéké, a fermented cassava product, during traditional small-scale preparation. Int $J$ Food Microbiol 106, 131-136.

De Bruyne, K., Camu, N., Lefebvre, K., De Vuyst, L. \& Vandamme, P. (2008). Weissella ghanensis sp. nov., isolated from Ghanaian cocoa fermentation. Int J Syst Evol Microbiol 58, 2721-2725.

Ennahar, S. \& Cai, Y., (2004). Genetic evidence that Weissella kimchii Choi et al. 2002 is a later heterotypic synonym of Weissella cibaria Björkroth et al. 2002. Int J Syst Evol Microbiol 54, 463-465.

Franz, C. M. A. P., Vancanneyt, M., Vandemeulebroecke, K., De Wachter, M., Cleenwerck, I., Hoste, B., Schillinger, U., Holzapfel, W. H. \& Swings, J. (2006). Pediococcus stilesii sp. nov., isolated from maize grains. Int J Syst Evol Microbiol 56, 329-333.

Gevers, D., Huys, G. \& Swings, J. (2001). Applicability of rep-PCR fingerprinting for identification of Lactobacillus species. FEMS Microbiol Lett 205, 31-36.

Gonzalez, J. M. \& Saiz-Jimenez, C. (2002). A fluorimetric method for the estimation of $\mathrm{G}+\mathrm{C}$ mol\% content in microorganisms by thermal denaturation temperature. Environ Microbiol 4, 770-773.

Gregersen, T. (1978). Rapid method for distinction of Gram-negative from Gram-positive bacteria. Eur J Appl Microbiol Biotechnol 5, 123127.

Jakava-Viljanen, M., Murros, A., Palva, A. \& Björkroth, K. J. (2008). Lactobacillus sobrius Konstantinov et al. 2006 is a later synonym of Lactobacillus amylovorus Nakamura 1981. Int J Syst Evol Microbiol 58, 910-913.

Jayne-Williams, D. J. (1976). The application of miniaturized methods for the characterization of various organisms isolated from the animal gut. J Appl Bacteriol 40, 189-200.

Kostinek, M., Specht, I., Edward, V. A., Schillinger, U., Hertel, C., Holzapfel, W. H. \& Franz, C. M. (2005). Diversity and technological properties of predominant lactic acid bacteria from fermented cassava used for the preparation of Gari, a traditional African food. Syst Appl Microbiol 28, 527-540.

Lee, J.-S., Lee, K. C., Ahn, J.-S., Mheen, T.-I., Pyun, Y.-R. \& Park, Y.-H. (2002). Weissella koreensis sp. nov., isolated from kimchi. Int J Syst Evol Microbiol 52, 1257-1261.

Magnusson, J., Jonsson, H., Schnürer, J. \& Roos, S. (2002). Weissella soli sp. nov., a lactic acid bacterium isolated from soil. Int J Syst Evol Microbiol 52, 831-834.

Marmur, J. (1961). A procedure for the isolation of deoxyribonucleic acid from microorganisms. J Mol Biol 3, 208-218.

Nout, M. J. R. \& Motarjemi, Y. (1997). Assessment of fermentation as household technology for improving food safety: a joint FAO/WHO workshop. Food Contr 8, 221-228.

Nout, M. J. R. \& Sarkar, P. K. (1999). Lactic acid food fermentation in tropical climates. Antonie van Leeuwenhoek 76, 395-401.

Padonou, S. W., Nielsen, D. S., Hounhouigan, J. D., Thorsen, L., Nago, M. C. \& Jakobsen, M. (2009). The microbiota of Lafun, an African traditional cassava food product. Int J Food Microbiol 133, 2230 .

Pitcher, D. G., Saunters, N. A. \& Owen, R. J. (1989). Rapid extraction of bacterial genomic DNA with guanidium thiocyanate. Lett Appl Microbiol 8, 151-156.

Schillinger, U. \& Lücke, F.-K. (1987). Identification of lactobacilli from meat and meat products. Food Microbiol 4, 199-208.

Schillinger, U., Boehringer, B., Wallbaum, S., Caroline, L., Gonfa, A., Holzapfel, W. H. \& Franz, C. M. A. P. (2008). A genus-specific PCR method for differentiation between Leuconostoc and Weissella and its 
application in identification of heterofermentative lactic acid bacteria. FEMS Microbiol Lett 286, 222-226.

Stackebrandt, E. \& Kandler, O. (1979). Taxonomy of the genus Cellulomonas, based on phenotypic characters and deoxyribonucleic acid-deoxyribonucleic acid homology, and proposal of seven neotype strains. Int J Syst Bacteriol 29, 273-282.

Tanasupawat, S., Shida, O., Okada, S. \& Komagata, K. (2000). Lactobacillus acidipiscis sp. nov. and Weissella thailandensis sp. nov., isolated from fermented fish in Thailand. Int J Syst Evol Microbiol 50, 1479-1485.

Wayne, L. G., Brenner, D. J., Colwell, R. R., Grimont, P. A. D., Kandler, O., Krichevsky, M. I., Moore, L. H., Moore, W. E. C., Murray, R. G. E. \& other authors (1987). International Committee on Systematic Bacteriology. Report of the ad hoc committee on reconciliation of approaches to bacterial systematics. Int J Syst Bacteriol 37, 463464. 